\title{
Learning provided by the transformation of a written text into a multimedia text
}

\author{
Maria Rosário Rodrigues \\ Department of Sciences and Technologies \\ College of Education of the Polytechnic Institute of Setúbal \\ Setúbal, Portugal \\ rosario.rodrigues@ese.ips.pt
}

\author{
Paulo Feytor Pinto \\ Department of Sciences of Communication and Language \\ College of Education of the Polytechnic Institute of Setúbal \\ Setúbal, Portugal \\ paulo.feytor@ese.ips.pt
}

\begin{abstract}
This paper is a critical reflection about teaching practices of two professors responsible for the teaching of Portuguese Language and Information and Communications Technology, a subject of the degree in Elementary Education. The reflection is based on results collected through participant observation during lessons with two classes, through the final individual reflections written by all students of both classes, through three tasks produced by some students and, finally, through interviews with these students.

The set of activities under consideration were intended to develop the competence of narrative writing and of a multimedia text production. It was found, however, that new more relevant learning has taken place in other areas: the production of the script, a tool that transforms the written text into a multimedia text, and the recording of planned speaking by children who collaborated in the creation of the PhotoStory.
\end{abstract}

\section{Keywords: Portuguese language, ICT, learning.}

\section{INTRODUCTION}

This text is an opportunity to reflect on practices developed in the context of the curricular unit (UC) Portuguese Language and Information and Communication Technologies (LPTIC), part of the 3rd year of the curriculum of the Bachelor's Degree in Elementary Education (LEB). The main feature of the UC is the partnership between two different scientific areas, the Portuguese Language (LP) and Information and Communication Technologies (ICT). The harmonization of these two areas has not always been simple because professors come from diverse professional backgrounds and different scientific cultures. Their collaborative work aimed at giving students two sets of different but complementary theoretical orientations and tools. Students were expected to realize that ICT is not only entertaining but that can promote interesting results when used for learning the LP.

With this paper we will critically reflect on the work in LPTIC, especially on the last task suggested to students. We try to understand if it was a promoter of learning and therefore consider its use in the future.

\section{CONTEXT OF STUDY}

LPTIC curriculum integrates a variety of tasks or activities for students to perform in pairs. The final set of activities is to write a text to be transformed into a PhotoStory multimedia text. The latter is created by the end of the semester, after the students' first initiation to pedagogic practice with children. Assuming that student assessment must enhance their own participation making them aware of their performance, students have to choose the work they want to be more relevant for their assessment.

The UC was attended by fifty-one students divided into two class groups. Every week, each group had two classes, one with each professor.

The last set of activities had three steps: (a) writing a story in Portuguese, (b) creation of the script to adapt the story to a multimedia text; (c) production of a PhotoStory after the story. These activities were first introduced by the language professor who suggested, after negotiation, a common compulsory beginning for the narration. He gave the students the exposition of the context and the conflict that should trigger the plot. The students were therefore expected to freely create and write the actions of the plot and its final resolution. The following phase, the script, was closely supported by both professors and the students should plan what media to use in the final multimedia text: plot, pictures, speech in subtitles or voiceover, and music. Eventually, the PhotoStory had to be produced according to the script plan. To make sure there was a shared pattern for all students' productions, the PhotoStory could have no more than eight slides and last for no more than three minutes.

Since this project is suggested shortly after the first time the students had been observing and reflecting on pre-school and primary school contexts, both professors encourage them to involve children in the construction of images or sound for the project. We wanted students to experience how their future pupils react to building a digital narrative.

\section{THEORETICAL FRAMEWORK}

The growing role ICT play in our daily lives and the inexplicable case of love between children and these technologies [11] force us to consider their implications for the learning of reading and writing. Among several potential uses of ICT for language learning, we highlight the digital stories as a contribution to the development of skills of reasoning, language and creativity. [16] Whatever option is chosen it is essential to enhance the role of the teacher and his/her strategies for the success of technology-based learning [4]. 
Our strategy started with a story built by the students, because we believe digital narratives reveal the art of storytelling using multimedia elements, such as image, sound and music [5]. Digital storytelling is a powerful tool for creating stories either for teachers or for students. The adoption of either a point of view or a dramatic question may interest and motivate students [12]. Under this perspective, we proposed a beginning narrative whose initial conflict was the vanishing of Santa Claus. By associating the process of writing to the construction of a digital narrative, writing was assigned a significant role which may determine the success of the project through increased motivation and commitment [11].

This methodology fosters the development of multiple literacies, not only digital literacy, through the increase of the students' mastery in the use of technologies, but also visual literacy through the production of images, and writing literacy, with the development and conclusion of the suggested narrative. The construction of meaning is achieved by the image, interacting with the text and sound, because students assign a "proper meaning to the image, which along with the other modes, mobilizes prior knowledge that interact in the construction of new knowledge" [8 ].

Students involved in this activity are likely to become educators or teachers in the 1st or 2 nd cycle of basic education (grades 1-6). Since one of our goals is to trigger educational use of technologies with their future pupils, we were concerned with the design of activities that might be used with children of these educational stages. Although preschool students are not readers, their surroundings can be equally rich. In this set of activities, the educator has planned the tasks and gave freedom to the children to select scenarios and characters, to create dialogues and invent their own stories and the results were equally interesting from the point of view of development of imagination and creativity [7].

The final examination at the end of each cycle (grades 4 and 6), socially highly valued, do not evaluate some of the skills that students must develop. Among these skills is reading aloud. The use of podcasts by children allows the separation between reading time and listening time and becomes a facilitator of loud reading self-assessment. Thus, the voiceover included in a multimedia product can have the same advantages of a podcastl.

These activities with PhotoStory were worked in pairs because we believe that work in a group of this size guarantees the access of both members to the computer and encourages sharing and trading ideas with consequent learning resulting from a process of socialization of knowledge [14].

\section{METHODOLOGY}

Since LPTIC was organized and taught by two professors with different cultures, perceptions about the reality of practices do not always coincide. We therefore felt the need

\footnotetext{
${ }^{1}$ Project "Conta-nos uma História" has available many examples of use of Podcast in education at http://www.crie.minedu.pt/index.php?section $=416$
}

for a retrospective reflection about our action to analyze it [1] and, if necessary, adjust it. We adopted a perspective of reflecting on action and about the action trying to better understand our performance, but also looking to improve it [10].

\section{A. Data collection}

Data collection began in the classroom during regular working sessions with the students. In these sessions, teachers have adopted a participatory observation approach [3], trying to record all comments made by students, who verbalized difficulties or successes they were reaching.

The last session of the UC was a time of sharing when all students presented their peers the learning they deemed most relevant. This moment was very intense and useful as it allowed us to perceive some of the reasons why students choose the work they want to be more relevant for their assessment. This session was followed by the collection of documents produced by the students. At this stage were collected not only the three products produced over the activity but also the final written individual reflection produced by each student.

We then felt the need to reinforce this data with the views of some of the students. Focus Group participants should be carefully selected [9], so we organized two sessions for which we selected eight students. The criteria behind this choice related to our perception of students' involvement in that activity because it seemed that greater involvement would allow a deeper reflection including more problems and more suggestions.

LPTIC is a UC of the first semester, but the Focus Group only took place during the second semester. We intended to get away from the discussion of facts, making it clear there was no influence on the students' final mark of the UC. We wanted them to feel no constraints due to the assessment of their work. We opted for the group interview technique since it was a situation of young students interviewed by their professors and we wanted them to feel as comfortable as possible [6]. Thus, the group interview was conducted in depth, trying to confirm conjectures and stimulate new ideas. It was organized in two sessions with three participants each. The sessions were audio recorded - fifty-six minutes - and subsequently transcribed. The participants of the focus group were all students who chose this activity to be assessed for their final mark. We assumed that students who had devoted more to the activity would therefore more willingly reflect upon it. Interestingly we found out that the students selected by this criterion were also those who had a better assessment in this activity and who have chosen to carry out part of the activity with children.

In short, the data collection began in the classroom with field notes on teaching practice, continued with the analysis of the developed products - continuation of the story, script, PhotoStory and final reflection - and finished with two Focus Group sessions.

\section{B. Data analysis}

Data analysis based on the crossing of information from different data collection tools made it possible for us to 
consider a more diverse set of analysis topics and at the same time confirm a phenomenon or detect different isolated phenomena [17].

Analysis categories were structured around two main topics: the methodology adopted in LPTIC and the use of PhotoStory on education, with children. Each of these categories has been subdivided according to data that was being collected and led to the analytical framework presented in the next section, dedicated to the results.

Our data analysis can be considered thematic and transversal. Thematic because it was organized under a set of themes; transversal because the references to the themes are analyzed across several data sources and several different observations [2].

\section{RESULTS}

In this section we will try to summarize the results we deem more important. One of the interesting aspects relates to the final written reflections of all LPTIC students. Of all fifty-one reflections produced, forty-five $(88 \%)$ referred to the PhotoStory activity. We therefore assume that most students were not indifferent to it. Still on the reflections, only two students considered it an inadequate activity and in both cases because they considered PhotoStory too simple and/or limited from a technological point of view.

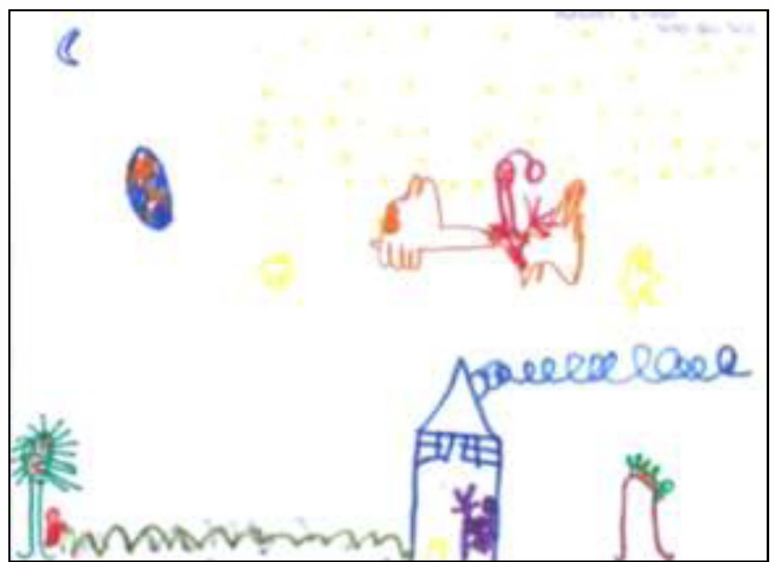

Figure 1 - Illustration created by one of the children

\section{A. About the method adopted during the activity}

As far as the adopted methodology is concerned, the first relevant comment relates to its various stages. The option to make it mandatory for students to participate in all phases of the activity (text writing, selection or creation of the images, sound recording, and production of subtitles) relates to the building of the sense of authorship that, in our view, provides greater creativity and involvement of students in the project.

The next question relates to the compulsory text we started the activity with. In class, both professors perceived the idea had been a bad option because several students reacted negatively considering it would restrain their imagination and creativity. So this was an issue discussed during group interviews but it was inconclusive. Some students said they had not been limited but others said that all photostories ended up having the same central theme, which became monotonous, especially in moments of sharing with the class. On the other hand, some students considered it a good option for it was not too driven and they could eliminate the time of decision on the subject to choose. The statement of one of the interviewed students seems enlightening:

"No ... We felt freedom. It was just an initial picture and then we could carry on as we wanted. It was only a guideline and it was good. And we felt a lot of freedom. Anyone could recreate whatever he wanted. But guidance is better than "do as you please." And then we start going around not knowing what to decide. "

The doubt remains about what do the students that were not interviewed think. They are also those who have had lower performance in this activity. Did they feel this option was a constraint? With the collected data we could not get answer to this question.

When we first considered this activity the idea was to foster the written use the Portuguese language through writing a tale (phase one), rewriting it into a script (phase two), and writing subtitles (phase three). This idea of ours was thwarted by the comments of the students who claimed the script was the hardest phase of the work but did not originate any rewriting. It rather consisted on the division of the original text into excerpts that were complemented with pictures or drawings. The true difficulty was the search for a shared text-image meaning, as a student puts it:

"Yes, I remember that, after having the pictures, I remember I had to do many rearrangements on the division... as a matter of fact this image is also included in this part of the text, of the story, it does not make sense to put it in another image."

The 2nd year LEB syllabus includes a UC on technologies where students practice how to prepare a presentation. They explore different tools namely PhotoStory. So when they attend LPTIC, the vast majority of students already knows the tool and technology is not an obstacle for the development of the activity. They also mentioned that writing a story is not hard since it is a regular task they have. Apparently, the focus should be the script that is considered something new, the hardest phase of the project and the one that enabled more learning.

"I know there was a first script and that there was a totally different second one. [The group colleague] wrote a first script, I grabbed it, I read it to my mother and my mother told me that the text did not make any sense ... I had to rewrite the story, send it to [the group colleague] and we felt that we had to work with the second one because the first was a senseless mixture, it had been necessary to read it to someone from outside to realize its flaws, for us it was just fine ..." 
One of the rules the final product had to comply to was to last for no more than three minutes and have up to eight images. Some students report difficulties in meeting these goals not only because the final product had over time, but also because they produced too many images. It seems to us that this problem is associated with the script structure that only contains two columns: one for the text and another for the image. However, when asked about the reformulation of the script, the students showed no need to do so.

Despite considering the script good, the students mentioned the need for planning the distribution the roles by several children and include the motivation for the construction of images, as pointed out by one of the interviewed students:

"We've had to plan [...] we had to build: how do we do, to contact the nursery, to organize, to write the story, to divide the story, to do the script, choose what we wanted children to draw, to know how to explain it to the children, we had to tell the story, for them to understand what we wanted"

Not all groups had the same opportunity to work with children because, for example, some had worked with 5 and 6 -graders and did not consider the conditions promoted this type of work. Hence, the solutions were very diverse: one group worked with children within the family, others went to kindergartens or schools of 1 st cycle where they had trained and others went to schools where some relative worked. Basically, there was a very widespread desire to experience the educational environment the students want to work on in the future, as a student put it:

"It's very rare for us to do field work in our course. We make many hypothetical work and that really was a hands-on job. For example, besides drawing, the children narrated the story we had to record. And it was necessary to repeat the recordings ... and they say, that's not very good, I want to record again ... it was all very nice, very rewarding. Sometimes we thought it was already good and the kids still wanted to do it again ... but we managed to reconcile all wills."

Besides the importance of the script, the active participation of children in audio recording revealed another unexpected result, the important contribution that the activity may have for the explicit development of oral expression, opening another perspective for fruitful relationships between language and technologies.

We believed that group interviews, far from assessment and the distortion of truth it may cause, could be a good opportunity for students to discuss the integration of ICT in their future practices. Are ICT promoting new methodologies or do we run the risk of ICT reinforcing old behaviorist methodologies reinforcing the role of the teacher who knows everything? The opinion of the participants is divided. Some of them first stressed the role of the teacher:
"For example, last year we [...] had created a class with PhotoStory. We prepared a presentation to teach a class; that is, it is a good way to show elsewise in the classroom. Instead of always reading a book or doing exercises. It's another sort of presentation."

But the following students already considered the possibility and even some advantages of using ICT with pupils in a constructivist learning perspective.

"And we can even build it with them. Instead of asking always the same tasks, we can make a PhotoStory about some content they are learning. About what they liked most or they had most difficulties with. It is another way to manage. It is a way to work together and use Photo Story to learn. "

Students however were not unanimous and we risk that more traditional teaching, almost instinctively, overlaps a change in practices with the use of ICT. The use of ICT by children also depends on the specific conditions our students meet in schools where they train. Some have technological equipment but others do not. Students even refer the need, in some cases, to diversify the activities because there aren't enough computers for all children to use simultaneously. Furthermore, they refer other factors such as the profile of the class and of the teacher in charge of the group hosting the trainee.

\section{B. About the use of PhotoStory in education}

PhotoStory is unevenly referred by students. The overwhelming majority says that it is a simple program and very easy to learn, but there are two cases in which students consider it an obstacle to the development of the activity. One of the interviewed students claimed to have had many problems with the sound recording and acknowledged she had used another program that allowed her to insert sound tracks previously recorded.

The adoption of this tool in this context was decided upon previous experiments where children swiftly developed technologic skills, although some problems were observed in the management of the duration of each drawing or picture exposure [13]. Those students who used this tool with children found it adequate.

"Me and [my colleague], we used it with 4-graders, they used it at pre [-school], it proves we can use it in different cycles."

\section{A student from another project: "I think so!"}

Indeed, it seems the tool fits the work with children though its use is questioned by some teacher trainees. Working with children is referred to as very rewarding and students are nearly consensual about the benefits of involving children in tasks. When drawings and voiceover were made by children it was noticeable a strong involvement with several requests for repetition to get the perfect result. Team work with pupils seems a success factor and students refer to it as a motivation to do well, linked to children's learning: "The burden of responsibility, of being 
something that will become public, that it depends on them if it shines or not ...".

Some students mentioned specific difficulties especially related to sound recording apparently dependent on the age and level of pupils concerned. That's the case of expressive loud reading that requires practice from grade 1 to grade 4 , including the explicit rehearsal of planned oral presentations particularly diction, intonation, rhythm, volume and emphasis. These facts confirm previous research pointing out that loud reading recording promotes self-assessment and improves quality [14].

\section{FINAL CONSIDERATIONS}

Regarding the methodology adopted in the activity, there seems to be some need to strengthen the constructivist perspective of learning. Although that is the methodology we have adopted we observed that some students view these activities only as contributions for the teacher to have greater diversity of resources for a methodology centered in himself. This aspect should be better approached throughout the UC possibly with examples of ICT use by pupils in class.

Another problem underlying the very concept of the UC is that it is taught by two very different professors who are not simultaneously in the classroom. It is a situation difficult to manage so we seek to articulate with careful planning and with frequent references to the work done by the other professor, to highlight the articulation between the two components of UC. In spite of the difficulties, participants refer positively to the cooperation between professors and the two subject areas. It widens their perspectives on the possibilities of using ICT for language learning. Especially about the PhotoStory activity there are very positive reviews. One of the students, in his final written reflection wrote:

"I highlight Photo Story tool as the one that triggered my interest, and was the most labor-intensive activity, involving the two components of UC harmoniously."

Despite this view expressed by students, we believe that there is still much work to do between the professors of UC. Our two very different cultures, whose details we only get to know over collaboration, call for deeper coordination so that no different names or meanings are ascribed to the same concept or activity. This was the first academic year this pair of professors taught together this UC and we think it is necessary to continue this work for the next year. Still we think the odyssey of writing this text was a better chance of knowing our differences and enhance mutual confidence levels.

As for the activity proposed to students, we build the perception that the difficulty is not in the production of content (LP) or the use of technological means (ICT), but on the relationship between the two of them, during the restructuring of content for the multimedia environment through the script. Thus, the script proves to be the central point so its reformulation should be considered to promote the treatment of the Portuguese language. In the script should be included a new column for time and another one for suggestions of combination of different resources. This way, the script is not reduced to a division the original text into slices.

As for the use of PhotoStory, data analysis allows the conclusion that it adapts well to work with children. However, it has limitations that can hinder the work of our students. If we use this tool adapted to the youngest, as we have done so far, we think it is necessary to strengthen the presentation of the tool limitations, notably those relating to manipulation of sound.

The suggestion to work with children to build the final product was a success factor for those who implemented it and proved to be a relevant time for the development of orality. Since we cannot make this suggestion a mandatory prescription, because it is not a UC with Teaching Practice, we think this possibility should be enhanced with the presentation of some products made by students from previous years and an explanation on how to plan the activity with children. This explanation may include not only the more formal aspects of permits to work with children, but also organizational aspects of activities with guidance on the involvement of children and the possible ways to motivate and organize them.

\section{REFERENCES}

[1] Alarcão, I. (1996). Reflexão crítica sobre o pensamento de D. Schön e os programas de formação de professores. In I. Alarcão (Org.), Formação reflexiva de professores:Estratégias de supervisão (pp. 939). Porto: Porto Editora.

[2] Bardin, L. (2004). Análise de Conteúdo. Lisboa: Edições 70.

[3] Bogdan, R., \& Biklen, S. (2013). Investigação qualitativa em Educação. Porto: Porto Editora.

[4] Botelho, F. (2009). Aprendizagem do português e multiliteracias. Medi@ções Revista OnLine, vol.I, número 1. Setúbal: Escola Superior de Educação, Pp 60-75. Consultado em junho de 2015 e disponível http://mediacoes.ese.ips.pt/index.php/mediacoesonline/article/viewFil $\underline{\mathrm{e} / 5 / 7}$

[5] Figueiredo, M. (2003). As histórias e o desenvolvimento das competências linguísticas na educação pré-escolar. Lisboa: Bola de Neve.

[6] Graue, M. E., \& Walsh, D. J. (2003). Investigação Etnográfica com Crianças: Teorias, Métodos e Ética. Lisboa: Fundação Calouste Gulbenkian.

[7] Jasmins, F., Lagarto, J. (2015). O Contributo das TIC na Criação de Histórias na Educaçãp Pré-Escolar in M.J. Gomes, A. J. Osório, Valente, L.(org.) Actas da IX Conferência Internacional de TIC na Educação Challenges 2015: Meio Século de TIC na Educação, Half a Century of ICT in Education. Braga: Universidade do Minho. pp. 1183-1196.

[8] Lourenço, C., Ramos, A. (2013). A Narrativa Digital na Aula de Lingua Portuguesa in M.J. Gomes, A. J. Osório, A. Ramos, Silva, B., Valente, L.(org.) Actas da VIII Conferência Internacional de TIC na Educação Challenges 2013: Aprender a qualquer hora e em qualquer lugar, learning anityme anywhere. Braga: Universidade do Minho. pp. 936-946.

[9] Martins, T. (2007). Concepção de uma CoP online: um estudo em torno da integração das TIC na disciplina de EVT. Dissertação de mestrado, Universidade de Aveiro,Aveiro. Disponível em $\underline{\text { http://biblioteca.sinbad.ua.pt/Teses/2007001198 }}$ 
[10] Oliveira, I. \& Serrazina, L. (2002). A reflexão e o professor como investigador. In GTI (Org.), Reflectir e Investigar sobre a prática profissional (pp. 29-42). Lisboa: APM.

[11] Papert, S. (1997). A Família em Rede. Lisboa: Relógio D`Água.

[12] Robin, B. (2008). Digital Storytelling: a powerful technology tool for the 21st century classroom. Theory into Practice, 47(3), (pp. 220 228). Consultado em julho de 2015 e disponível em http://digitalstorytellingclass.pbworks.com/f/Digital+Storytelling+A+ Powerful.pdf

[13] Rodrigues, M. R., \& Grácio, J. (2011). Os putos também fazem filmes? EXEDRA Publicação electrónica semestral da Escola Superior de Educação do Instituto Politécnico de Coimbra, (5), 37-55. Consultado em junho de 2015 e disponível em http://www.exedrajournal.com/docs/N5/03A-Rodrigues_Putos.pdf
[14] Silva, F., Rodrigues, M. R., \& Botelho, F. (2013). Fluência da leitura em voz alta: contributo da ultilização de Podcast para o desenvolvimento (Mestrado em Educação Pré-Escolar e Ensino do $1^{\circ}$ Ciclo do Ensino Básico). Setúbal: Escola Superior de Educação do Instituto Politécnico de Setúbal. Consultado em junho de 2015 e disponível em http://comum.rcaap.pt/handle/123456789/4669

[15] Vygotsky, L. (1978). Mind in society: The development of higher psychological processes. Cambridge, Mass: Harvard University Press

[16] Xu, Y., Park, H., \& Baek, Y (2011). A New Approach Toward Digital Storytelling: An Activity Focused on Writing Self-Efficacy in a Virtual Learning Environment. Journal of Technology \& Society 14(4) 181191. Consultado em junho de 2015 e disponível em http://www.ifets.info/journals/14 4/16.pdf

[17] Yin, R. K. (2010). Estudo de caso: planejamento e métodos (Ana Thorell, Trans.). Porto Alegre: Bookman. 